\title{
Removal of chromium by Staphylococcus saprophyticus subsp. bovis strain 1
}

\section{Alekhya Iyengar,}

\section{Malavalli Subbaiah Usha*}

Department of Microbiology, Centre for Post Graduate Studies, Jain University, 18/3, 9th main, 3rd block, Jayanagar, Bangalore 560011, India
The present study was taken up to carry out the removal of chromium by bacteria. Chromium is a heavy metal which is of concern as it causes chromium toxicity in both plants and animals. The tanneries are a major source of chromium release into the water bodies, and hence this study is aimed at identifying the potential chromium-tolerant bacterium and at studying the bacterium for its maximum tolerance and chromium removal capacity.

A total of 20 samples each of soil and industrial effluents were collected from the Peenya industrial area, Bangalore, India. The bacterial isolates were screened for chromium resistance by supplementing the nutrient media with $300 \mu \mathrm{g} / \mathrm{ml}$ of chromium. The growth of the bacteria was measured in terms of O.D. at $670 \mathrm{~nm}$. The isolates were further screened by increasing the concentration of chromium from 300 to $3000 \mu \mathrm{g} / \mathrm{ml}$. The isolate S10$5 \mathrm{c}$ which showed better resistance to chromium compared to other isolates was identified as Staphylococcus saprophyticus subsp. bovis strain 1 based on 16S rRNA sequencing. Optimization of temperature, $\mathrm{pH}$, carbon sources, and nitrogen sources was carried out for the removal of chromium by $S$. saprophyticus subsp. bovis strain 1. Atomic absorption spectrophotometric analysis was carried out for the removal of chromium by $S$. saprophyticus subsp. bovis strain 1 in the mineral salts medium supplemented with $300 \mu \mathrm{g} / \mathrm{ml}$ of chromium.

Out of 40 soil and industrial effluent samples collected, a total of 51 isolates were obtained. Out of 51 isolates, 7 isolates gave the highest O.D. values in the presence of $300 \mu \mathrm{g} / \mathrm{ml}$ of chromium. The isolate $\mathrm{S} 10-5 \mathrm{c}$ showed maximum tolerance up to $3000 \mu \mathrm{g} / \mathrm{ml}$ of chromium. S. saprophyticus subsp. bovis strain 1 was able to remove $2 \%$ of chromium in the medium at the end of 24 hours under optimized conditions.

It can be concluded that the organism Staphylococcus saprophyticus subsp. bovis strain 1 can be used for the removal of chromium from industrial effluents.

Key words: chromium removal, Staphylococcus saprophyticus subsp. bovis strain 1, atomic adsorption spectrophotometry analysis, heavy metal removal, bioremediation

\footnotetext{
*Corresponding author. E-mail: bg.ushams@gmail.com
} 


\section{INTRODUCTION}

The term "heavy metal" was first introduced in 1817 where Gmelin divided metals into non-metals, light metals, and heavy metals. The reason they are called heavy metals is because of them having a higher density and also due to the fact that they are a primary environmental concern due to their property of bioaccumulation and biomagnification. The metal concentration gets magnified as it reaches the higher trophic levels; this phenomenon is known as biomagnification (Packnikar et al., 2003). Not all heavy metals are of environmental concern. Heavy metals like lead, zinc, copper, arsenic, nickel, cadmium, chromium, mercury, etc. are of serious concern as these metals are usually toxic to the human body even at low concentrations. Chromium is one such metals which is used extensively and in large quantities in some of the industries. Chrome plating is often done to make a metal more anti-corrosive. Stainless steel and high-speed tool steel have 3 to $5 \%$ of chromium in them. Chrome yellow is a commonly used yellow pigment in paints. The industry which makes use of large quantities of chromium salt is a tannery. For the purpose of tanning leather, chromium salts are used which strengthen the cross linking between the collagen fibres. These above-mentioned heavy metals are present in the body in low concentrations through food and water we consume and also through the air we breathe. When concentration exceeds the tolerable amount, it poses a threat by being toxic and causes acute and fatal ailments (Babel, Kurniawan, 2004). Such toxicity is not confined to humans. Plants and animals are equally affected by these heavy metals.

Bacteria are considered to be an ideal choice for heavy metal removal due to their potential to adapt to stressful conditions. They have mechanisms which help them produce the necessary extracellular and intracellular enzymes which aid in the removal of such stress. In case of heavy metal stress, there is complexation of the heavy metal within the cell or outside the cell or the heavy metal is accumulated inside the cell after being reduced into a less toxic form (Nies, 1999). Some of the general mechanisms seen in bacteria are also of use in heavy metal removal. In some bacteria, the slime layer which is produced also brings about the surface adhesion of heavy metals.

Faisal and Hasnain (2004) investigated the conversion of $\mathrm{Cr}$ (VI) to $\mathrm{Cr}$ (III) in industrial effluents. They isolated the strains from the effluents based on their tolerance to chromium salt $\mathrm{K}_{2} \mathrm{CrO}_{4}$ which was around $40 \mathrm{mg} /$ $\mathrm{ml}$ on nutrient agar and $25 \mathrm{mg} / \mathrm{ml}$ in nutrient broth. These isolates exhibited multiple metal $(\mathrm{Ni}, \mathrm{Zn}, \mathrm{Mn}, \mathrm{Cu}, \mathrm{Co}, \mathrm{Pb}$ ) and antibiotic (streptomycin, ampicillin, kanamycin, tetracycline, and chloramphenicol) resistance. It was also noted that their reduction potential was not affected by the different metallic salts present in the effluents. A bacterium isolated from tannery effluents was evaluated for its property to remove hexavalent chromium from the effluent. This strain showed tolerance to chromium to a range of $500 \mathrm{mg} / \mathrm{L}$ and could remove $35 \%$ of the metal in 72 hours (Karmakar, Ray, 2013). Sukumar et al. (2013) used Bacillus subtilis SS-1 strain isolated from the soil samples collected from an electroplating industry to remove chromium (VI). This strain of Bacillus showed a maximum resistance of $600 \mathrm{mg} / \mathrm{L} .98 .7 \%$ of chromium could be removed from the experimental setup. FTIR was performed which gave the results that carboxyl and amide groups were involved in chromium (VI) removal.

The objective of this study is to isolate, identify and screen the chromium-resistant bacteria and also to check for their efficiency in removal of chromium.

\section{MATERIALS AND METHODS}

\section{Chemicals}

Potassium dichromate was used as the source of chromium. The chemicals and media used were procured from Himedia Private Limited, Mumbai, India. The chemicals were of analytical grade. 


\section{Sample collection}

Soil and effluent samples were collected from the Peenya industrial area, Bangalore. Twenty samples each of soil and effluents were collected and stored in plastic containers. These samples were refrigerated at $4{ }^{\circ} \mathrm{C}$ until use.

\section{Isolation of bacteria}

Each of the collected soil and effluent samples were serially diluted and plated on nutrient agar. Plates were incubated at $37{ }^{\circ} \mathrm{C}$ for 24 hours. Pure cultures of the isolates were maintained on nutrient agar for further use.

\section{Screening of the isolates for chromium re- sistance}

Each isolate was inoculated into $50 \mathrm{ml}$ of nutrient broth supplemented with potassium dichromate at a concentration of $300 \mu \mathrm{g} / \mathrm{ml}$ and incubated at $37{ }^{\circ} \mathrm{C}$ for 24 hours. Growths of the isolates were measured in terms of O.D. at $670 \mathrm{~nm}$. The isolates which showed better growth compared to other strains were further screened for their tolerance to increasing concentrations of potassium dichromate ranging from 300 to $3000 \mu \mathrm{g} / \mathrm{ml}$ (Karmakar, Ray, 2013). Tolerance to different concentrations of the heavy metal by the isolates was measured in terms of O.D. at $670 \mathrm{~nm}$.

\section{Identification of the bacteria}

S10-5c which showed resistance to chromium was identified up to genus level based on biochemical tests (Krieg, Staley, 2010). The isolate was identified up to species level by $16 \mathrm{~S}$ rRNA sequencing.

\section{Optimization of temperature, ph, carbon} and nitrogen sources for heavy metal removal by bacteria

The effect of various parameters like temperature, $\mathrm{pH}$, carbon sources, and nitrogen sources on the removal of chromium by the isolate $\mathrm{S} 10-5 \mathrm{c}$ was checked. For temperature optimization, four different temperatures of $25,30,35$, and $40{ }^{\circ} \mathrm{C}$ were used. The $\mathrm{pH}$ was set to $5,6,7$, 8,9 , and 10 using $0.1 \mathrm{~N} \mathrm{NaOH}$ and $0.1 \mathrm{~N} \mathrm{HCl}$ (Congeevaram et al., 2007). The carbon sources used were glucose, sucrose, starch, arabinose, maltose, and fructose at $0.2 \%$ concentration. The nitrogen sources used for the optimization were ammonium nitrate, beef extract, yeast extract, peptone, and sodium nitrate at $0.2 \%$ concentration. Mineral salts medium (MSM) was used to carry out optimization experiments. Flasks were incubated for 24 hours at $37^{\circ} \mathrm{C}$ and then growth was measured in terms of O.D. at $670 \mathrm{~nm}$.

The isolate $\mathrm{S} 10-5 \mathrm{c}$ was grown in mineral salts medium (Sepahi et al., 2008) with chromium at a concentration of $300 \mu \mathrm{g} / \mathrm{ml}$ under optimized conditions. The flask was incubated for $24 \mathrm{~h}$ following which the samples were centrifuged at $10,000 \mathrm{rpm}$ for $10 \mathrm{~min}$. The supernatants were collected and diluted 50 times. The diluted supernatants were analyzed using an atomic absorption spectrophotometer (AAS).

The sequence was deposited in NCBI GenBank using BankIt as the tool for obtaining the unique accession number.

\section{RESULTS}

Out of a total of 20 soil and 20 industrial effluent samples which were collected, 51 isolates were obtained which were morphologically distinct. When all these 51 isolates were exposed to $300 \mu \mathrm{g} / \mathrm{ml}$ concentration of potassium dichromate, they showed difference in their growth in terms of O.D. at $670 \mathrm{~nm}$. Seven isolates showed the potential to be chromium resistant (Table 1). Out of 51 isolates subjected to screening for growth in the presence of chromium, the isolates S1-6, E16-6b, E7-5c, E2-6c, and E5-6c showed an O.D. value of 0.01 . The O.D. values for these 7 isolates ranged between 0.15 and 0.38 . The isolate $\mathrm{S} 10-5 \mathrm{c}$ showed a highest O.D. of 0.38.

These screened isolates showed a difference in the range of tolerance to the increasing concentrations of the metals. Among 7 isolates subjected to screening at different concentrations of chromium the isolate $\mathrm{S} 10-5 \mathrm{c}$ could grow in a concentration up to $3000 \mu \mathrm{g} / \mathrm{ml}$ ( Table 2). The isolate E15-5c being least resistant to chromium could not grow in a concentration beyond $300 \mu \mathrm{g} / \mathrm{ml}$. 
Table 1. Growth of isolates in the presence of chromium in terms of O.D. at $670 \mathrm{~nm}$

\begin{tabular}{ccccccc}
\hline Sample & Chromium $(\mathrm{Cr})$ & Sample & Chromium $(\mathrm{Cr})$ & Sample & Chromium (Cr) \\
\hline E2-6a & 0.02 & E9-6 & 0 & S7-5 & 0.08 \\
\hline S8-5 & 0.06 & S17-5 & 0.11 & S2-5c & 0 \\
\hline E2-6b & 0.06 & S1-5b & 0.15 & S13-5 & 0 \\
\hline S14-5 & 0 & S7-6a & 0.13 & S16-6b & 0.01 \\
\hline E12-5b & 0.05 & S4-5 & 0.19 & E5-6c & 0.01 \\
\hline E7-6b & 0 & S15-6 & 0 & E12-5c & 0 \\
\hline E8-6a & 0.11 & S16-6a & 0.09 & E7-5c & 0.01 \\
\hline S1-5a & 0.1 & E5-6b & 0.19 & E5-6a & 0.02 \\
\hline E8-5a & 0.1 & E7-5b & 0.27 & E15-5a & 0 \\
\hline S16-6c & 0.09 & S8-6 & 0.01 & E4-6b & 0 \\
\hline E5-6c & 0.02 & E16-5b & 0.06 & S10-5a & 0 \\
\hline S18-6 & 0.21 & E7-5a & 0.12 & E17-5 & 0 \\
\hline S10-5c & 0.22 & E16-5a & 0.01 & S2-6 & 0.04 \\
\hline S9-6 & 0 & E15-5c & 0.15 & S7-6b & 0 \\
\hline S5-5 & 0.15 & S2-5b & 0.06 & E2-6c & 0.01 \\
\hline E12-5a & 0.17 & S1-6 & 0.01 & & \\
\hline S10-5b & 0.03 & S6-5 & 0.04 & & \\
\hline S18-5 & 0 & S2-5a & 0.15 & & \\
\hline
\end{tabular}

The isolate $\mathrm{S} 10-5 \mathrm{c}$ was found to be a coagulase-negative organism. It gave a positive result for urease and catalase. Acid production was seen in fructose, glucose, glycerol, maltose, sucrose, trehalose, and turanose on performing a carbohydrate fermentation test. The organism gave a negative result for coagulase and DNAse and also showed a negative result for nitrate reduction. Acid production in arabinose, mannose, cellobiose, rhamnose, fucose, and galactose was not seen. Based on Gram's staining and biochemical tests, the isolate $\mathrm{S} 10-5 \mathrm{c}$ was tentatively identified as Staphylococcus sps. On performing $16 \mathrm{~S}$ rRNA sequencing the isolate $\mathrm{S} 10-5 \mathrm{c}$ showed 98\% similarity with Staphylococcus saprophyticus subsp. bovis and hence was identified as Staphy- lococcus saprophyticus subsp. bovis strain 1 with the accession number KT895962 (Photos 1, 2).

When optimization of different parameters was carried out for removal of chromium by S. saprophyticus subsp. bovis strain 1 , the growth was higher at $35^{\circ} \mathrm{C}$ (Table 3). Growth was also seen at a temperature of 30 and $40{ }^{\circ} \mathrm{C}$ for S. saprophyticus subsp. bovis strain 1 . The optimum $\mathrm{pH}$ for the growth of the isolate $S$. saprophyticus subsp. bovis was found to be $\mathrm{pH} 8$ (Table 4). The organism showed growth in both $\mathrm{pH} 6$ and $\mathrm{pH} 7$; however, the growth was comparatively slower. Among the different sugars checked, glucose was found to influence the growth of the isolate $S$. saprophyticus subsp. bovis strain 1 compared to other sugars (Table 5). Among

Table 2. Growth of chromium-resistant bacteria in terms of O.D. values at $670 \mathrm{~nm}$ in the presence of varying concentrations of chromium ranging from 300 to $3000 \mu \mathrm{g} / \mathrm{ml}$

\begin{tabular}{ccccccccc}
\hline Sample & $\mathbf{3 0 0} \boldsymbol{\mu g} / \mathbf{m l}$ & $\mathbf{6 0 0} \mathbf{~ g} / \mathbf{m l}$ & $\mathbf{1 2 0 0} \boldsymbol{\mu g} / \mathbf{m l}$ & $\mathbf{1 8 0 0} \boldsymbol{\mu g} / \mathbf{m l}$ & $\mathbf{2 4 0 0} \boldsymbol{\mu g} / \mathbf{m l}$ & $\mathbf{3 0 0 0} \mathbf{~ g g} / \mathbf{m l}$ \\
\hline S18-6 & $0.22 \pm 0.03$ & 0.05 & 0.05 & 0 & 0 & 0 \\
\hline S10-5c & $0.38 \pm 0.03$ & 0.2 & 0.15 & $0.18 \pm 0.03$ & $0.08 \pm 0.03$ & $0.07 \pm 0.03$ \\
\hline S5-5 & 0.05 & 0.05 & 0 & 0 & 0 & 0 \\
\hline S1-5b & $0.23 \pm 0.03$ & 0.1 & $0.09 \pm 0.02$ & $0.04 \pm 0.01$ & 0.05 & $0.05 \pm 0.005$ \\
\hline E5-6b & 0.1 & 0.05 & 0.05 & 0.05 & 0 & 0 \\
\hline E7-5b & $0.35 \pm 0.05$ & 0.05 & 0.05 & 0.05 & 0.05 & 0.05 \\
\hline E15-5c & $0.12 \pm 0.03$ & 0 & 0 & 0 & 0 & 0 \\
\hline
\end{tabular}




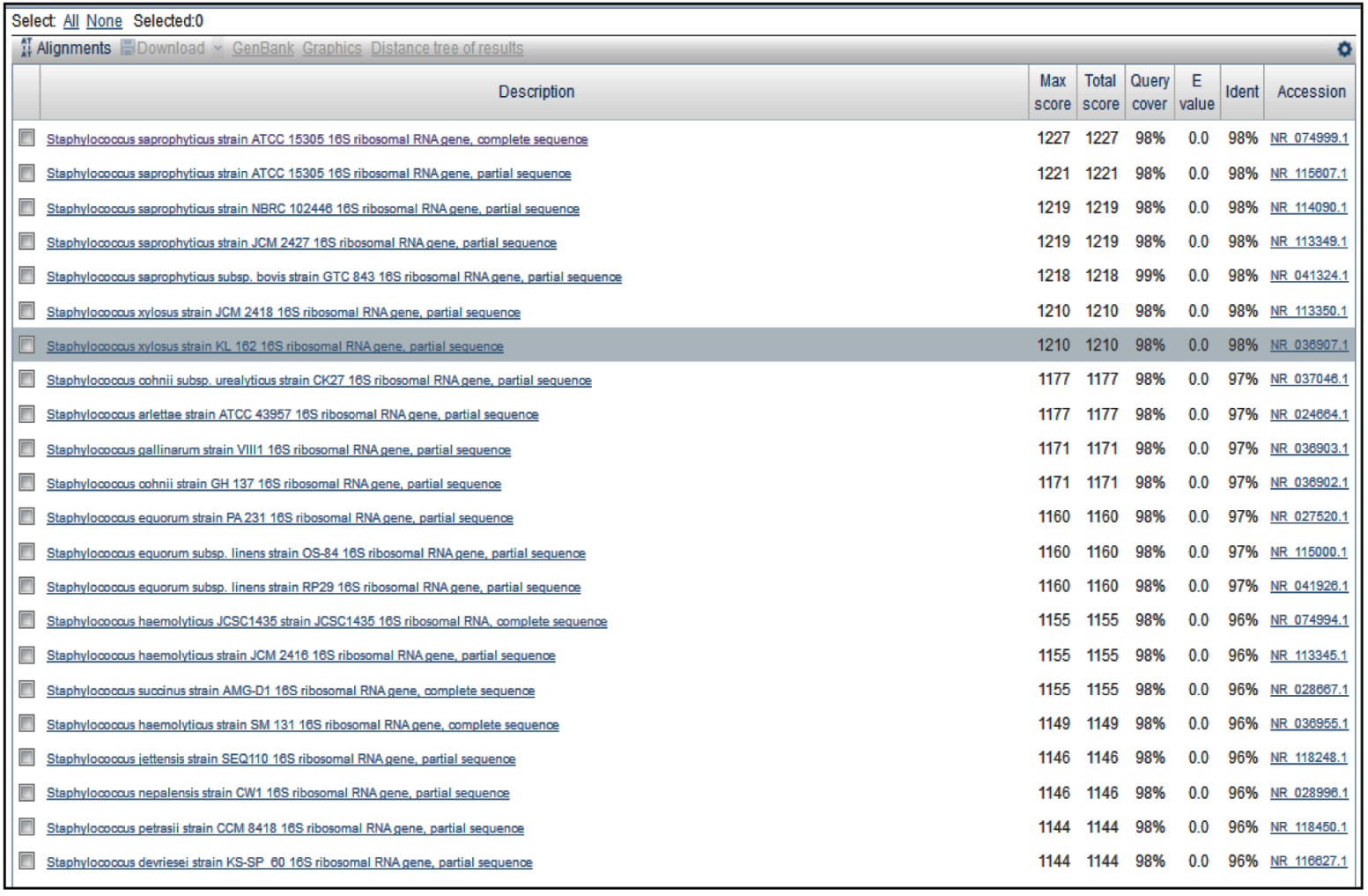

Fig. 1. Similarity index of the isolate S10-5c which was identified as Staphylococcus saprophyticus subsp. bovis strain 1

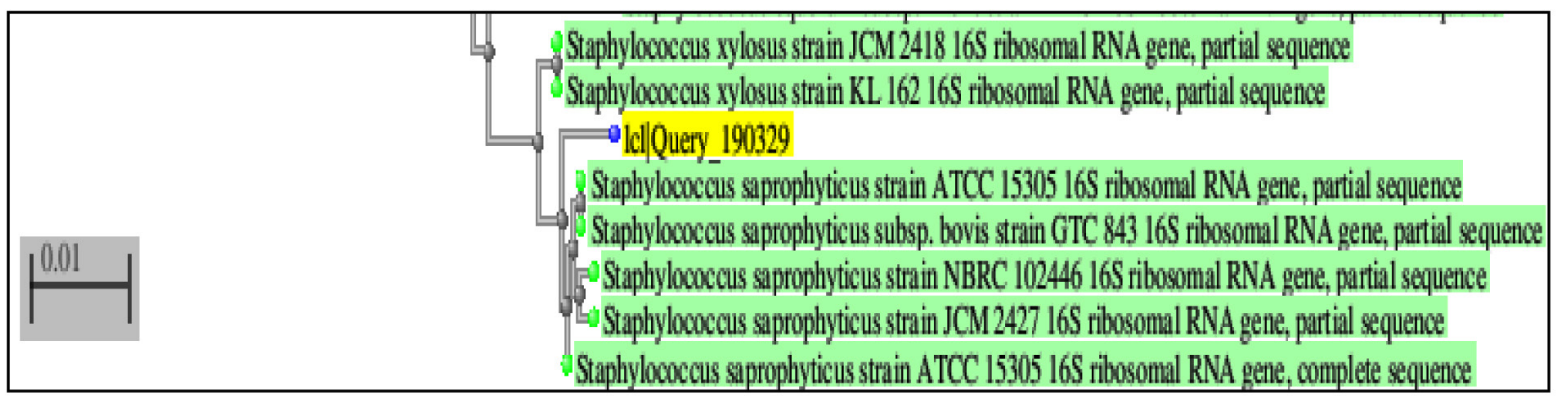

Fig. 2. Phylogenetic tree for Staphylococcus saprophyticus subsp. bovis strain 1

Table 3. Growth of Staphylococcus saprophyticus subsp. bovis strain 1 in terms of O.D. values at $670 \mathrm{~nm}$ at different temperature

\begin{tabular}{c|c|c|c|c}
\hline Sample & $25^{\circ} \mathrm{C}$ & $30{ }^{\circ} \mathrm{C}$ & $35^{\circ} \mathrm{C}$ & $40^{\circ} \mathrm{C}$ \\
\hline S10-5c & 0 & $0.03 \pm 0.005$ & $0.05 \pm 0.01$ & 0.02 \\
\hline
\end{tabular}

Note: Values are the means of triplicates \pm standard error

Table 4. Growth of Staphylococcus saprophyticus subsp. bovis strain 1 in terms of O. D. values at $670 \mathrm{~nm}$ at different $\mathrm{pH}$

\begin{tabular}{c|c|c|c|c|c|c}
\hline Sample & pH 5 & pH 6 & pH 7 & pH 8 & pH 9 & pH 10 \\
\hline S10-5c & 0 & $0.036 \pm 0.005$ & 0.05 & $0.056 \pm 0.005$ & $0.043 \pm 0.005$ & $0.07 \pm 0.02$ \\
\hline
\end{tabular}

Note: Values are the means of triplicates \pm standard error 
Table 5. Growth of Staphylococcus saprophyticus subsp. bovis strain 1 in terms of O.D. values at $670 \mathrm{~nm}$ in the presence of different carbon sources

\begin{tabular}{|c|c|c|c|c|c|c|}
\hline Sample & Sucrose & Glucose & Arabinose & Maltose & Starch & Fructose \\
\hline S10-5c & $0.033 \pm 0.006$ & $0.086 \pm 0.01$ & $0.023 \pm 0.006$ & $0.02 \pm 0.01$ & $0.03 \pm 0.01$ & $0.03 \pm 0.01$ \\
\hline
\end{tabular}

Note: Values are the means of triplicates \pm standard error

Table 6. Growth of Staphylococcus saprophyticus subsp. bovis strain 1 in terms of O.D. values at $670 \mathrm{~nm}$ in the presence of different nitrogen sources

\begin{tabular}{c|c|c|c|c|c}
\hline Sample & $\mathrm{NaNO}_{3}$ & $\mathrm{NH}_{4} \mathrm{NO}_{3}$ & Peptone & Beef extract & Yeast extract \\
\hline $\mathrm{S} 10-5 \mathrm{c}$ & 0.01 & $0.03 \pm 0.01$ & $0.083 \pm 0.005$ & $0.10 \pm 0.01$ & $0.043 \pm 0.01$ \\
\hline
\end{tabular}

Note: Values are the means of triplicates \pm standard error

the different nitrogen sources checked for the growth of S. saprophyticus subsp. bovis, beef extract was found to be better compared to other nitrogen sources (Table 6).

After optimization of temperature, $\mathrm{pH}$, carbon and nitrogen sources, the atomic absorption spectrophotometry revealed that the organism S. saprophyticus subsp. bovis strain 1 could remove $2 \%$ of total chromium content from the solution over a period of $24 \mathrm{hrs}$.

\section{DISCUSSION}

According to our study, Staphylococcus saprophyticus subsp. bovis strain 1 could grow in presence chromium compared to other isolates. Becker and Palsson (2005) reported glucose to be the best carbon source for the growth of Staphylococcus sps which is in agreement with the present study where Staphylococcus saprophyticus subsp. bovis strain 1 could grow the best when glucose was the sole carbon source. The optimum conditions for the growth of Staphylococcus sps is a $\mathrm{pH}$ of $6-7.5,37^{\circ} \mathrm{C}$, and glucose as carbon source (Prakasham et al., 2006) which is close to what has been reported in this study where the optimum $\mathrm{pH}$ was seen to be 8 and optimum temperature was reported as $35{ }^{\circ} \mathrm{C}$. Staphylococcus sps have been reported to be hexavalent chromium resistant by many researchers. Zahoor and Rehman (2009) reported that S. capitis is a hexavalent chromium reducing bacteria. It could tolerate up to $2800 \mu \mathrm{g} / \mathrm{ml}$ of $\mathrm{Cr}$ which is similar to that of Staphylococcus saprophyticus subsp. bovis strain 1 which could tolerate up to $3000 \mu \mathrm{g} / \mathrm{ml}$. The optimum growth for $S$. capitis was reported at $37^{\circ} \mathrm{C}$ which is similar to that of S. saprophyticus subsp. bovis strain 1 whose optimum temperature was reported to be $35^{\circ} \mathrm{C}$. S. capitis could remove $81 \%$ of $\mathrm{Cr}(\mathrm{VI})$ from the media after $96 \mathrm{~h}$ which is much higher than what has been reported for Staphylococcus saprophyticus subsp. bovis strain 1 which is $2 \%$ after $24 \mathrm{~h}$. It was reported by Mistry et al. (2010) that Staphylococcus sp. could tolerate a concentration of $25 \mathrm{mM}$. The optimum $\mathrm{pH}$ was 7 and temperature was reported to be $32{ }^{\circ} \mathrm{C}$. Shakoori et al. (2010) reported that Staphylococcus sps could tolerate chromium at a concentration up to $1.6 \mathrm{mg} / \mathrm{ml}$. It was able to show optimum growth at a $\mathrm{pH}$ of 8 and a temperature of $37^{\circ} \mathrm{C}$. Using a diphenylcarbazide method it was determined that Staphylococcus sps could reduce 91\% of chromium over $24 \mathrm{~h}$ which is higher than what has been reported for Staphylococcus saprophyticus subsp. bovis strain 1 .

From the above discussion it can be seen that the optimum conditions of the present study are in agreement with the research performed by others. S. saprophyticus subsp. bovis strain 1 which is a chromium-resistant bacterium grew well under optimum conditions of $35{ }^{\circ} \mathrm{C}$ and $\mathrm{pH}$ 8. This organism used glucose as the carbon source and beef extract as the nitrogen source.

\section{CONCLUSIONS}

From the present study it can be concluded that the organism Staphylococcus saprophyticus 
subsp. bovis strain 1 is a chromium-resistant bacterium with tolerance to a concentration of $3000 \mu \mathrm{g} / \mathrm{ml}$ of chromium, hence it can be used for the removal of chromium.

Received 18 December 2015

Accepted 1 March 2016

\section{References}

1. Babel S, Kurniawan TA. Cr (VI) removal from synthetic wastewater using coconut shell charcoal and commercial activated carbon modified with oxidizing agents and/or chitosan. Chemosphere. 2004; 52: 951-67.

2. Becker SA, Palsson AB. Genome-scale reconstruction of the metabolic network in Staphylococcus aureus N315: an initial draft to the two-dimensional annotation. BMC Microbiology. 2005; 5(8).

3. Congeevaram S, Dhanarani S, Park J, Dexilin $\mathrm{M}$, Thamaraiselvi K. Biosorption of chromium and nickel by heavy metal resistant fungal and bacterial isolates. J Hazard Mater. 2007; 146: 270-7.

4. Faisal M, Hasnain S. Microbial conversions of $\mathrm{Cr}$ (IV) to $\mathrm{Cr}$ (II) in industrial effluent. Afr J Biotechnol. 2004; 3: 610-7.

5. Karmakar M, Ray RR. Characterization of a hexavalent chromium reducing bacterial strain isolated from tannery effluents of Kolkata. Int J Pharm Biol Arch. 2013; 4(2): 337-41.

6. Krieg NR, Staley JT. (2). Bergey's Manual of Systematics Bacteriology. Baltimore: Williams Co.

7. Mistry K, Desai C, Lal S, Patel K, Patel B.
Hexavalent chromium reduction by Staphylococcus sp. isolated from Cr (VI) contaminated land fill. Intern J Biotechnol Biochem. 2010; 6(1): 117-29.

8. Nies DH. Microbial heavy metal resistance. Appl Microbiol Biotechnol. 1999; 51: 730-50.

9. Packnikar KM, Pethkar AV, Puranik PR. Bioremediation of metalliferous wastes and products using inactivated microbial biomass. Ind J Biotechnol. 2003; 2: 426-43.

10. Prakasam RS, Rao CS, Rao RS, Lakshmi GS, Sarma PN. L-asparaginase production by isolated Staphylococcus sp. - 6A: design of experiment considering interaction effect for process parameter optimization. J Appl Microbiol. 2006; 102(5): 1382-91.

11. Sepahi AA, Golpasha ID, Emami M, Nakoda AM. Isolation and characterization of crude oil degrading Bacillus sps, Iran J Environ Health Sci Eng. 2008; 5(3): 149-54.

12. Shakoori RF, Tabassum S, Rehman A, Shakoori AR. Isolation and characterization of $\mathrm{Cr}^{6+}$ reducing bacteria and their potential use in bioremediation of chromium containing wastewater. Pakist J Zool. 2010; 42(6): 651-8.

13. Sukumar C, Janaki V, Seralathan KK, Shanthi K. Biosorption of chromium (VI) using Bacillus subtilis SS- 1 isolated from soil samples of electroplating industry. Clean Techn Environ Policy. 2013; 16(2): 405-13.

14. Zahoor A, Rehman A. Isolation of Cr (VI) reducing bacteria from industrial effluents and their potential use in bioremediation of chromium containing wastewater. J Environ Sci. 2009; 21: 814-20. 


\section{Alekhya Iyengar, M. S. Usha}

\section{STAPHYLOCOCCUS SAPROPHYTICUS BAKTERIJOS BOVIS PORŪŠIO 1 PADERMĖS PANAUDOJIMAS CHROMUI ŠALINTI}

Chromas yra sunkusis metalas, toksiškas augalams ir gyvūnams, todèl keliantis rūpestị. Odų raugyklos yra pagrindinis chromo, išleidžiamo it vandens telkinius, šaltinis, todèl šio tyrimo tikslas buvo nustatyti chromą toleruojančias bakterijas, taip pat ištirti jų didžiausią toleruojamą chromo kiekị ir šalinimo gebą. Iš viso tyrimui surinkta po 20 mėginių dirvožemio ir pramoninių nuotekų Peenya industrinèje vietoveje Bangalore (Indija). Buvo tikrinamas bakterijų izoliatų atsparumas chromui papildant maitinamąją terpę $300 \mu \mathrm{g} / \mathrm{ml}$ chromo. Chromo koncentracija buvo didinama iki $3000 \mu \mathrm{g} / \mathrm{ml}$. Iš surinktų 40 méginių gautas 51 izoliatas, iš kurių 7 turèjo didžiausias O. D. reikšmes esant $300 \mu \mathrm{g} / \mathrm{ml}$ chromo. Izoliatas S10-5c, pasižymejjęs didžiausia - $3000 \mu \mathrm{g} / \mathrm{ml}$ chromo - tolerancija, 16S rRNR geno sekos kaitos metu identifikuotas kaip Staphylococcus saprophyticus bakterijos bovis porūšio 1 padermè. Remiantis gautais rezultatais padaryta išvada, kad Staphylococcus saprophyticus bakterijos bovis porūšio 1 padermè gali būti naudojama chromui šalinti iš pramoninių nuotekų.

Raktažodžiai: chromo šalinimas, Staphylococcus saprophyticus bakterijos bovis porūšio 1 padermé, atominès absorbcijos spektrofotometrinè analizè, sunkiụjų metalų šalinimas, bioremediacija 